\title{
ВІЙСЬКОВА КАФЕДРА ЛЬВІВСЬКОГО ПОЛІТЕХНІЧНОГО ІНСТИТУТУ У ПОВОЄННОМУ ДЕСЯТИЛІТТІ (1944-1956)
}

\author{
Лариса ШЕЛЕСТАК \\ Львівський національний університет імені Івана Франка, \\ кафедра історичного краєзнавства \\ вул. Університетська, 1, Львів, 79000, Україна \\ e-mail: larashelestak@ukr.net
}

Розглянуто та проаналізовано діяльність військової кафедри Львівської політехніки у повоєнному десятилітті. Навчання офіцерів запасу на військових кафедрах був важливим аспектом вишколу молодшого командного складу радянської армії. У студії використано архівні матеріяли, статті періодики, нормативно-правові акти радянських органів влади. На основі джерельного матеріялу проаналізовано діяльність військової кафедри у перші роки іiі існування, ії матеріяльної бази та офіцерського складу, розглянуто особливості теоретичного навчання студентів та практичної вишколу на табірних зборах.

Ключові слова: Львівська політехніка, офіцери запасу, військова кафедра, військова освіта в CPCP.

Від часу військового втручання сусіда-агресора на територію України, наша держава робить все, щоб покращити власну військову могутність, в тому числі належно проводити військовий вишкіл офіцерів Збройних сил України. Відповідно до постанови Кабінету Міністрів України від 10 березня 2017 р. № 133 “Про утворення військових навчальних підрозділів вищих навчальних закладів та внесення змін у додаток до Порядку проведення військової підготовки громадян України за програмою підготовки офіцерів запасу"' у деяких вищих навчальних закладах України впроваджується навчання офіцерів запасу на військових кафедрах. Тобто використовуються методи минулих поколінь щодо збільшення військового потенціялу держави. У радянський період військові кафедри були ледь не у кожному виші, зокрема, у Львові після Другої світової війни із 15 вищих навчальних закладів, військове навчання проводилось на 9-ти. Відновлення військового навчання при найпрестижніших Львівських вищих навчальних закладах (Львівському національному університеті імені Івана Франка чи Національному університеті “Львівська політехніка”) на сьогодні не передбачено, оскільки ця справа $є$ надзвичайно затратною. Однак, ще в недалекому минулому при цих вишах діяли потужні кафедри військової підготовки, які навчали студентів

\footnotetext{
${ }^{1}$ Кабінет Міністрів України. Постанова від 10 березня 2017 р. № 133 “Про утворення військових навчальних підрозділів вищих навчальних закладів та внесення змін у додаток до Порядку проведення військової підготовки громадян України за програмою підготовки офіцерів запасу," Верховна Рада України, отримано доступ 01.07.2018, http://zakon.rada.gov.ua/laws/show/ $133-2017-\% \mathrm{D} 0 \% \mathrm{BF}$
} 
на різних військово-облікових спеціяльностях. Ще до кінця 90-х рр. минулого століття при Львівській політехніці діяла військова кафедра, а фактично інститут, однак, його військова сила, як і він сам, залишились у минулому.

Автор ставить перед собою мету дослідити формування та діяльність кафедри військової підготовки Львівського політехнічного інституту (тепер Національний університет “Львівська політехніка") на самому початку іiі становлення, тобто в повоєнному десятилітті: 1944-1956 рр., проаналізувати стан матеріяльної частини та кадрового потенціялу військової кафедри цивільного вишу, та охарактеризувати процес навчання студентів на військовій кафедрі, ідеологічну діяльність офіцерів кафедри у насадженні норм радянського (чужсого) війська в Галичині, формуванні мілітарного радянського суспільства. Верхня межа студії обрана, враховуючи політико-ідеологічні зміни в СРСР, які стали наслідком XX з'їзу КПРС.

Відновлення Львівських вищих навчальних закладів відбувалось у завершальний період німецько-радянської війни, коли на Галичину вдруге повернулась радянська влада. Згідно з наказом Всесоюзного комітету у справах вищої школи при РНК СРСР № 417 від 2 вересня 1944 р. відповідно до розпорядження Раднаркому СРСР № 17580-р від 29 серпня 1944 р. відновлено діяльність Львівського політехнічного інституту․․ Користуючись постановою Ради народних комісарів СРСР № 413 від 13.04.1944 р. "Про військову підготовку студентів вищих навчальних закладів", Всесоюзний комітет у справах вищої школи при РНК СРСР видав наказ № 86 від 16 вересня 1944 р. “Про затвердження структури інституту”, в яку входила кафедра військової підготовки ${ }^{3}$.

Від самого початку своєї діяльности кафедра не мала постійного приміщення. Спочатку військова кафедра розміщувалась на третьому поверсі однієї із середніх шкіл міста* при вулиці Нікоровича ${ }^{4}$ (тепер - вул. Професорська, 2). Тут кафедра використовувала 12 кабінетів і мансарду на горищі: клас-кабінет з автосправи три кімнати, клас із експлуатації та ремонту, клас загальновійськової тактики та топографії, клас вогневого вишколу, клас військової радіостанції, авдиторія для дисциплін зв'язку, кабінет начальника кафедри, кабінет навчальної частини кафедри та викладацький кабінет. Також було приміщення для зберігання зброї, без жодної системи безпеки та охорони. Стрілецький тир облаштували в підвальному приміщенні головного корпусу інституту. Стрілецьке оснащення тиру було майже відсутнє, позаяк адміністрація інституту не виділяла кошти на

\footnotetext{
${ }^{2}$ Історична довідка ЛПІ, Державний архів Львівської області (далі ДАЛО), ф. Р-120 (Львівський політехнічний інститут), арк. 5. (Посилаючись на ф. Р-120, оп. 6, спр. 92-а, арк. 6.)

${ }^{3}$ Історична довідка ЛПІ, ДАЛО. ф. Р-120, арк. 6. (Посилаючись на ф. Р-120, оп. 32, спр. 2, арк. 11-13, 29-30.)

* Імовірно йдеться про Четверту вищу гімназію імені Яна Длугоша, що за перед Другою світовою війною розміщувалась при вулиці Нікоровіча (від 1946 р. - вул. Професорська).

${ }^{4}$ Отчет о работе института за 1944-1945 уч. г., ДАЛО, ф. Р-120, оп. 5, спр. 2, арк. 21.
} 
ISSN 2078-6077. Наукові зошити історичного факультету Львівського університету. 2018-2019. Випуск 19-20. Proceedings of History Faculty of Lviv University. 2018-2019. Issue 19-20.

ремонт та облаштунок приміщення. У перший рік своєї роботи кафедра ще не мала облаштованого штурм-містечка

На подвір'ї головного корпусу інституту, при вул. Сталіна, $12^{*}$ (тепер - вул. С. Бандери $)^{6}$, був гараж, де зберігалися автомашини кафедри. Щоб проводити практичні заняття із водіння, використовували об'їзні дороги Львова i ті, що вели за місто. Навчальних майстерень, де б зберігалась матеріяльна частина автомобілів, кафедра не мала. Тому, практичне навчання ремонту автотранспорту офіцери організовували та проводили на авторемонтних заводах ${ }^{7}$, що ускладнювало проводити заняття. Однак, незважаючи на недостатній авдиторний фонд, класи були укомплектовані всіма необхідними навчальними засобами: скринею з піском, рельєфом місцевости масштабом 1:10000 у класі тактики та топографії, кабінет вогневого вишколу та інженерної підготови був оснащений плакатами гвинтівки зразка 1891/30, зразками мін, інженерними інструментами. У класі вивчення матеріяльної частини автомобілів на плакатах були зображені розрізні блоки радянських автомашин, деталі двигуна. Кабінет зв' язку використовував плакати польових телефонних апаратів УНА-Ф, УКА-Н, радіодеталей із лампами, та діючий макет радіостанції I3P ${ }^{8}$. Цікавий той факт, що класи військової кафедри в зимовий період погано опалювались. Так, у грудні 1945-1946 н. р. в результаті проведеної перевірки старшим інспектором відділу військової підготовки УУЗ ВКВШ майором Рябініним, температура у класах досягала нуля. Траплялися випадки, коли цілі групи покидали авдиторію, тим самим зриваючи заняття 9 .

Військова кафедра отримувала своєчасно і в повному обсязі все табельне обладнання, розрізну зброю та топографічні карти. Однак, підручників та методичних посібників на кафедрі майже не було. Книжки надходили лише від відділу бойової підготовки Автомобільного управління Червоної армії, яке пізніше, щоб вирішити цю проблему, рекомендувало звернутися у відділ зв'язку Військового округу ${ }^{10}$.

Уже на 1946-1947 н. р. на балансі кафедри був автопарк із 13 автомашинами, 3 яких 11 вантажні та 2 легкові Газ-61, які періодично здавали в ремонт. Однак, автопарк був впорядкований на низькому рівні, оскільки на ремонт та утримання автомашин не вистачало працівників. Особовий склад автопарку налічував

${ }_{5}^{5}$ Отчет о работе военной кафедры за 1945-1946 уч. г., ДАЛО. ф. Р-120, оп. 12, спр. 11, арк. 15-16.

* Від грудня 1944 р. до 1961 р. - вулиця Сталіна; до 1992 р. - вул. Миру.

${ }^{6}$ Довідник перейменувань вулиць і площ Львова XIII-XX ст., ред. Б. В. Мельник, (Львів: Світ, 2001), 7.

${ }^{7}$ Отчет о работе военной кафедры за 1945-1946 уч. г., ДАЛО, ф, Р-120, оп. 12, спр. 11, арк. 17.

${ }^{8}$ Постановление СНК СССР, директивные письма СНК УССР и Всесоюзного кабинета по делам высшей школы при СНК СССР (1945-1946), ДАЛО, ф. Р-120, оп. 12, спр. 10, арк. 5.

${ }^{9}$ Отчет о работе военной кафедры за 1945-1946 уч. г., ДАЛО, ф. Р-120, оп. 12, спр. 11, арк. 9.

${ }^{10}$ Там само, арк. 19. 
всього одного механіка та четверо водіїв, не було жодного слюсаря ${ }^{11}$. Начальником автопарку був старший лейтенант Карпов ${ }^{12}$.

У 1949 р. при військовій кафедрі появилась парк-стоянка автомашин, придбано електрозасоби для машин, був обладнаний радіоклас 3 електрифікованим радіополігоном, закуплена власна кіноустава та 30 науковотехнічних фільмів. Класи обладнали без витрат коштів інституту, силами офіцерів, лаборантів і навіть членів сімей офіцерів ${ }^{13}$.

Питання перемістити кафедру військової підготовки розглянуто на засіданні бюро партійної організації Львівського політехнічного інституту 27 червня 1950 року. Як зазначав генерал-майор Голубєв, розмови про перенесення кафедри велися тривалий період, та директор ${ }^{* 14}$ інституту С. М. Ямпольський особисто запевнив його, що переміщувати ії не буде ${ }^{15}$. Проте, станом на 27 червня був виданий наказ директора таки перенести кафедру військової підготовки. Цікаво, що під час обговорення наказу деякі представники партії були обурені тим, що військову кафедру переводять 39 авдиторій у $13^{16^{* *}}$. Маємо всі підстави вважати, що кафедру військової підготовки перемістили згідно із наказом директора інституту в кінці 1949-1950н. р., оскільки на початок 1950-1951н. р. працівники кафедри займались обладнанням навчальних кабінетів новими навчальними стендами, матеріяльною частиною автомобілів, навчальними кіноплівками. Планували облаштувати клас для проведення лабораторних робіт та кабінет тактики ${ }^{17}$. Відкриття нового тиру військової кафедри відбулось наприкінці вересня 1950 p. $^{18}$, а тому, зважаючи, що тир вже існував у приміщенні головного корпусу інституту станом на 1946 р., автор припускає: військова кафедра таки переїхала в нове приміщення.

${ }^{11}$ Протоколы заседаний кафедры за 19 апреля 1946 г. - 23 мая 1946 г., ДАЛО, ф. Р-120, оп. 12 , спр. 12 , арк. 1 .

12 Там само, арк. 2.

${ }^{13}$ Підсумкова доповідь про результати марксистсько-ленінської підготовки офіцерів військових кафедр і військовій підготовці студентів вишів Прикарпатського військового округу за 1948 1949 н. р., ДАЛО, ф. П-4 (Львівський міський комітет КПУ), оп. 1, спр. 315, арк. 39.

* До 1961 року усіма вищими навчальними закладами, крім університетів, керували директори, яких призначали наказом Міністра вищої і середньої спеціальної освіти СРСР. Наказом МВССО СРСР від 29 березня 1961 р. у всіх вищих навчальних закладах СРСР було запроваджено ректорати.

${ }^{14}$ Микола Буцко. Державний університет “Львівська політехніка”: 1894-1994. (Львів: Видавництво Державного університету “Львівська політехніка”, 1994), 145.

${ }^{15}$ Протоколи засідань партійного бюро за 1950 р., ДАЛО, ф. П-380 (Партійний комітет Львівського політехнічного інституту), оп. 1, спр. 68, арк. 139.

${ }^{16}$ Там само, арк. 140.

** Інформація щодо часу і місця переміщення військової кафедри ЛПІ можливо присутня в наказах директора інституту, які на разі недоступні. Ці дані уточнить автор.

${ }^{17}$ Протоколы заседаний кафедры за 1950-1951 уч. г., ДАЛО, ф. Р-120, оп. 12, спр. 84, арк. 13 зв.

${ }^{18}$ Там само, арк. 3 зв. -5 . 
ISSN 2078-6077. Наукові зошити історичного факультету Львівського університету. 2018-2019. Випуск 19-20. Proceedings of History Faculty of Lviv University. 2018-2019. Issue 19-20.

У наступному навчальному році кафедра володіла двома кабінетами із вивчення навчальної частини автомобіля та кількома кабінетами радіозв'язку ${ }^{19}$. У 1952-1953 н. р. організували клас артилерії, однак своєї лабораторії кафедра так і не мала, використовуючи для занять лабораторію технології нафти Нафтового факультету ${ }^{20}$. А на початку лютого 1953 р. кафедрі було передано ще кілька авдиторій під клас артилерійно-топографічної служби, кабінет паливномастильних матеріялів (ГСМ), кабінет ремонту автомобілів, клас двигунів внутрішнього згоряння, кабінет радіотехнічної спеціяльности, авдиторія загальновійськового циклу та кімнату для самостійної роботи студентів ${ }^{21}$.

Першим начальником кафедри військової підготовки Львівського політехнічного інституту був гвардії інженер-підполковник Коваленко П. П. ${ }^{22}$ Він вступив у конфлікт із директором інституту С. М. Ямпольським, коли самовільно, “в обхід” адміністрації, відпустив у відрядження до Німеччини старшого лейтенанта Голобородька ${ }^{23}$. Керівництво інституту на засіданні партійного бюро звинувачувало інженер-підполковника Коваленка в тому, що офіцери кафедри не відповідали званню викладача інституту, були неписьменні, та наголошувало, що необхідно поповнити устаткування матеріяльної бази кафедри. Адміністрація інституту вважала за потрібне звернутись до Штабу Військового округу для перевірки роботи кафедри ${ }^{24}$. Через згадану вище перевірку майора Рябініна, що відбулась у грудні 1945 р. та через недостатній освітній рівень, звільнили шість викладачів та взяли на роботу семеро нових офіцерів. До моменту затвердження штату, у квітні 1946 р., на військовій кафедрі налічувалось 17 працівників ${ }^{25}$. Тоді ж кафедру очолив генерал-майор Голубєв А. П. ${ }^{26}$, який перебував на посаді начальника кафедри до виходу на пенсію, у 1957 р. Генерал-майор Червоної армії Аркадій Павлович Голубєв народився в 1897 р., за національністю росіянин $^{27}$. Від грудня 1917 р. перебував у лавах більшовицької армії ${ }^{28}$, брав

${ }^{19}$ Протоколы заседаний кафедры за 1951-1952 уч. г., ДАЛО, ф. Р-120, оп. 12, спр. 109, арк. 1 зв.

${ }^{20}$ Протоколы заседаний кафедры за 1952-1953 учебный год, ДАЛО, ф. Р-120, оп. 12, спр. 123 , арк. 3.

${ }^{21}$ Там само, арк. 21 зв. -22.

${ }^{22}$ Постановление СНК СССР, директивные письма СНК УССР и Всесоюзного кабинета по делам высшей школы при СНК СССР (1945-1946), ДАЛО, ф. Р-120, оп. 12, спр. 10, арк. 5 зв.

${ }^{23}$ Протоколы заседания партийного бюро за 1945 г., ДАЛО, ф. П-380, оп. 1, спр. 3, арк 24.

${ }^{24}$ Там само, арк 9.

${ }^{25}$ Отчет о работе военной кафедры за 1945-1946 уч. г., ДАЛО, ф. Р-120, оп. 12. Спр. 11. арк. 3.

${ }^{26}$ Протоколы заседаний кафедры за 19 апреля 1946 г. - 23 мая 1946 г., ДАЛО, ф. Р-120, оп. 12, спр. 12 , арк. 3.

${ }^{27}$ Погранеи. Всесоюзный форум пограничников, 29 жовтня 2013, отримано доступ 9 серпня 2018, http://www.pogranec.ru/showthread.php?t=25117\&page=11

28 “Голубев Аркадий Павлович," Кавалеры юбилейной медали “ХХ лет РККА”, 25 ноября 2012, отримано доступ 9 серпня 2018, http://zov1941.ucoz.ru/index/golubev_arkadij_pavlovich/0244 
участь у Громадянській війні (1917-1923) на території колишньої Російської імперії - Бессарабії та Дегестані. Був активним учасником німецько-радянської війни. Від 1942 р. у ранзі полковника він став начальником тилу П’ятої резервної армії, пізніше 63-ї армії, яку вкінці 1943 р. реорганізували у Третю гвардійську. У грудні 1942 р. Голубєву А. П. присвоєно рангу генерал-майора ${ }^{29}$. Учасник битви під Сталінградом. Від 1944 р. його призначили заступником начальника тилу Першого Білоруського фронту. Після завершення Другої світової війни був нагороджений орденом Леніна, двома орденами Червоного прапора, орденом Вітчизняної війни І ступеня та ін. ${ }^{30}$

Від початку свого створення кафедра як структурна одиниця вже радянського інституту виконувала ідейно-виховну функцію. За кожним факультетом призначали офіцера, який не тільки був відповідальний за військове навчання студентів та створення науково-військових гуртків та секцій, але й складав на кожного студента, що навчався на військовій кафедрі, так звану особову справу: вивчав повну біографію, особисті дані студента, характеристики 3 деканату ${ }^{31}$ та комсомольської організації ${ }^{32}$.

Зважаючи на те, що на Галичині наприкінці 1940-х - на початку 1950-х рр. діяло підпілля ОУН, у вищих навчальних закладах проводились репресії щодо студентів, які могли бути пов'язані із націоналістами. 3 цього приводу, в 1950 р., на засіданні партійного комітету Львівського політехнічного інституту обговорювали роботу відділу кадрів та приймальної комісії щодо їхньої пильности під час прийому документів і вказаних у них біографічних даних абітурієнтів. Зокрема, негативно висловлювались про механізм прийому студентів до інституту і представники військової кафедри. Так, генерал-майор Голубєв А. П. наголошував, що завданням кафедри військової підготовки була атестація студентів, а в особових справах не зазначено інформацію про рідних та чи були вони на окупованій території. Інженер-полковник Кніна Л. Г. запропонував вимагати у студентів через деканати повні біографії, щоб порівняти їх 3 тими, що вже були в особових справах, для кращого вивчення студентства ${ }^{33}$.

У 1952 р. трапився випадок відрахування студентів із інституту за “націоналістичну пропаганду”, який активно обговорювали на засіданні військової кафедри. Відрахованими були студенти п’ятого курсу Шах і Шалівський.

\footnotetext{
29 “Голубев Аркадий Павлович,” Странииы российской истории: Люди, события, воспоминания, документы..., отримано доступ 9 серпня 2018, http://russian-dossier.ru/taxonomy/ term/5977

${ }^{30}$ Погранеи. Всесоюзный форум пограничников, 29 жовтня 2013, отримано доступ 9 серпня 2018,

http://www.pogranec.ru/showthread.php?t=25117\&page=11

${ }^{31}$ Протоколи засідань партійного бюро за 1950 р., ДАЛО, ф. П-380, оп. 1, спр. 68, арк. 68.

${ }^{32}$ Протоколы заседаний кафедры за 1952-1953 учебный год, ДАЛО, ф. Р-120, оп. 12, спр. 123, арк. 24 зв.

${ }^{33}$ Протоколи засідань партійного бюро за 1950 р., ДАЛО, ф. П-380, оп. 1, спр. 68, арк. 68.
} 
ISSN 2078-6077. Наукові зошити історичного факультету Львівського університету. 2018-2019. Випуск 19-20. Proceedings of History Faculty of Lviv University. 2018-2019. Issue 19-20.

Незважаючи на добру характеристику та атестацію на офіцерів запасу Радянської Армії, вони так і не були в комсомолі ${ }^{34}$. Студенти друкували агітаційні листівки на горищі гуртожитку, а відтак були заарештовані як “вороги народу"35. Начальник кафедри наголошував, що велика кількість студентів має добрі характеристики та успішність, але у своїй біографії зазначали, що батько чи матір репресовані або мали родичів, зв'язаних із “бандерівцями”. Тому, закликав краще вивчати самих студентів, збирати автобіографічні дані студентів другого і четвертого курсів, тобто тих, які проходять табірні збори ${ }^{36}$.

Як члени ВКП(б) (згодом КПРС), офіцери кафедри вважали за потрібне вдосконалити механізм вивчення біографії студентів, які тільки-но потрапляли на військову кафедру. Полковник Григорян зауважував, що він як курсовий офіцер за наказом писав характеристики на студентів, яких він не знав, користуючись лише інформацією із характеристики декана факультету ${ }^{37}$. Майор Шабанов на засіданні кафедри висловився: “ворог пішов у підпілля $i$ застосовує всі засоби щоб втайти свою роботу. Не потрібно забувати те, щзо ми живемо там, де є сильний націоналістичний рух і тому нам слід бути пильними" 38 . Попри самокритичне ставлення офіцерів до якости політичної роботи кафедри, спостереження за студентами в інституті велись на потрібному, для радянських репресивних органів, рівні. Наприклад, у 1951 р. на табірних зборах офіцери дізналися, що студент хіміко-технічного факультету Бєлогаєв був заарештований та перебував у полоні.

Також під підозру потрапляли студенти, які з різних причин часто пропускали заняття в інституті ${ }^{39}$. Цікаво й те, що траплялися випадки, коли самі студенти скаржилися в деканат чи громадські організації при факультеті, що їм заважало вступати в комсомол. Так, наприклад, студент 4-го курсу Попович скаржився, що не може вступити в комсомол, бо боявся, що його вб'ють “бандерівці”"40.

У кінці 1940-х - початку 1950-х рр. активну роль у вишколі офіцерів запасу відігравали оборонні масові гуртки ТСОАВІАХІМ (до 1948 р., від 1951 р. ДТСААФ), в роботі яких брали участь офіцери військової кафедри. Основною метою цих гуртків було пропагувати та розвивати військово-політичний та спортивний вишкіл молоді. Станом на початок 1946-1947н. р. в інституті проводились регулярні заняття гуртків авто-, радіо-, мото- та стрілецької секції. Заняття автосекції проводились в 4-х групах, одна 3 яких - група професорськовикладацького складу. Для занять залучено четверо викладачів, що було

${ }^{34}$ Протоколы заседаний кафедры за 1951-1952 учебный год, ДАЛО, ф. Р-120, оп. 12, спр. 109, арк. 33 зв.

${ }^{35}$ Там само, арк. 34.

${ }^{36}$ Там само, арк. 33 зв.

${ }^{37}$ Там само, арк. 34.

${ }^{38}$ Там само, арк. 35.

${ }^{39}$ Там само, арк. 34 зв.

${ }^{40}$ Там само, арк. 34. 
недостатньо, зважаючи, що групи складалися по 90 осіб $^{41}$, а тому ефективність такого навчання зводилась до мінімуму. Усього автосекція охоплювала 246 осіб ${ }^{42}$.

Радіосекція складалася з двох гуртків: радистів-операторів і радистівконструкторів. Гурток радистів-операторів у 1949 р. нараховував 30 осіб. Гурток радистів-конструкторів був при радіокафедрі електротехнічного факультету та охоплював 12 осіб $^{43}$.

При інституті діяла сильна мотоциклетна секція, команди якої часто брали участь у міських чи міжуніверситетських змаганнях та виборювали перемогу. Наприклад, у червні 1949 р. команда інституту, на чолі із керівником секції інженер-підполковником Кніною Л. отримали перше місце на міському змаганні ${ }^{44}$.

Станом на 1949-1950 н. р. до роботи в інституті планували залучити ДТСАВ*, зокрема розглядали можливість готувати парашутистів. Проте, деякі викладачі кафедри, виступили проти роботи цього товариства в інституті. Наприклад Коваленко П. П. заявляв: “У нас є зв'язківиі, автомобілісти, мотоииклісти та ін., але з авіації у нас немає бази, немає спеціялістів”. У підсумку парашутисти були вилучені з плану підготови, а акцент зробили на гуртках ДТСАРМ: стрільцях-розрядниках, спортсменах-розрядниках, мотоциклістах та водіях-аматорах ${ }^{45}$.

У 1952-1953 н. р. в інституті діяли стрілецька секція, яку очолював підполковник Мадєєв Г., артилерійська секція - полковник Григорьєв, секція ПММ (ГСМ) - інженер-полковник Браз А. та секція зв'язку - підполковник Волков М. ${ }^{46}$ Заняття стрілецької секції проводили у вільний від навчання час. Бойовими набоями студенти стріляли на стрільбищі, що при вул. Клепарівській, тоді, як тир інституту був настільки перевантажений, що часу там стріляти не вистачало ${ }^{47}$.

Загалом, військове навчання в інституті розпочалося одразу, коли ЛПІ відновив роботу у 1944-1945 н. р. Військова кафедра готувала офіцерів запасу за двома військовими спеціяльностями: "офіцер запасу автомобільних військ"

${ }^{41}$ Інформація і звіти про роботу парторганізації, ДАЛО, ф. П-380, оп. 1, спр. 22, арк. 46.

42 Там само.

${ }^{43}$ Там само.

${ }_{44}$ Олександр, Браз, “Перемога інститутських мотоциклістів на міському кросі”, Радянський студент. № 22. (9 червня 1949): 3 .

* Від 1927 р. до 1948 р. існувало Товариство сприяння обороні й авіації та хімічному будівництву (ТСОАВІАХІМ); від 1948 р. до 1951 р. діяли Добровільне товариство сприяння армії (ДТСАРМ), Добровільне товариство сприяння авіяції (ДТСАВ) і Добровільне товариство сприяння флотові (ДТСФлот), які об'єдналися в єдине Добровільне товариство сприяння армії, авіації та флоту (ДТСААФ) в 1951 р. Діяльність цих товариств фінансували з державного бюджету.

${ }^{45}$ Протоколи засідань партійного бюро 1949 р., ДАЛО, ф. П-380, оп. 1, спр. 50, арк. 147.

${ }^{46}$ Протоколы заседаний кафедры за 1952-1953 учебный год, ДАЛО, ф. Р-120, оп. 12, спр. 123, арк. 24 зв., 34.

47 Протоколы заседаний кафедры (1953-1954 уч. г.), ДАЛО, ф. Р-120, оп. 12, спр. 142. арк. 75. 
ISSN 2078-6077. Наукові зошити історичного факультету Львівського університету. 2018-2019. Випуск 19-20. Proceedings of History Faculty of Lviv University. 2018-2019. Issue 19-20.

та “офіцер запасу військ зв'язку”48. Уже на початок 1945-1946 н. р. на кафедрі навчалось 1850 студентів, однак до кінця навчального року залишилось 1192. Серед причин різкого зменшення чисельности були незадовільні житловокомунальні умови, виїзд студентів польської національности до Польської Народної Республіки та неуспішність ${ }^{49}$.

Зауважимо, що військове навчання відбувалось у студентів усіх десяти факультетів інституту. Студенти сільськогосподарського та лісогосподарського факультетів проходили вишкіл за навчальними планами чотирирічного курсу, решта - п'ятирічного ${ }^{50}$. Важливо, що лише випускники електротехнічного факультету, відповідно до своєї спеціальности, навчались та отримували звання “офіцер запасу військ зв’язку”, тоді як студенти інших факультетів навчались за профілем “офіцери запасу автомобільних військ”

Загалом для всіх студентів читали такі курси: загальновійськовий вишкіл, тактику, вогневий вишкіл, топографію; з автомобільного профілю d автосправу, експлуатацію та авторемонт; з профілю зв'язку - службу зв'язку, телефонію, телеграф, військові рації та СЕС радіо ${ }^{52}$.

Негативним явищем у навчальному процесі було те, що всі викладачі кафедри спрямовували свою увагу на теорію, проводили лекції у вигляді диктанту, що не сприяло активності студентів під час занять ${ }^{53}$. Серед недоліків навчального процесу начальник кафедри Голубєв А. П. виділяв недостатню навченість студентів у поводженні зі зброєю, невміння студентів користуватись картами та компасами на місцевості із картою (як показували державні екзамени), недоліки муштрового вишколу та вимагав збільшити можливості практичного навчання студентів ${ }^{54}$.

У 1948-1949 н. р. в ЛПІ запровадили ще два профілі вишколу - “офіцер запасу служби постачання паливно-мастильних матеріялів" (ПММ) та “офіцер запасу артилерійно-топографічної служби"55.

Незалежно від профілів вишколу студенти проходили муштровий вишкіл, вивчали військову топографію, вогневий вишкіл, загальновійськову тактику, військово-інженерний вишкіл, протихімічний вишкіл та вивчали статути ${ }^{56}$. Проте,

${ }^{48}$ Отчет о работе института за 1944-1945 уч. г., ДАЛО, ф. Р-120, оп. 5. спр. 2, арк. 63.

49 Отчет о работе военной кафедры за 1945-1946 уч. г., ДАЛО, ф. Р-120, оп. 12, спр. 11, арк. 1 .

${ }^{50}$ Отчет о работе института за 1945-1946 уч. г., ДАЛО, ф, Р-120, оп. 5, спр. 4, арк. 39 зв.

${ }^{51}$ Там само, арк. 42.

52 Там само, арк. 29 зв., 32.

53 Там само, арк. 29 зв.

${ }^{54}$ Там само, арк. 32.

${ }^{55}$ Підсумкова доповідь про результати марксистсько-ленінської підготовки офіцерів військових кафедр і військовій підготовці студентів вишів Прикарпатського військового округу за 1948 1949 н. р., ДАЛО, ф. П-4, оп. 1, спр. 315, арк. 59.

${ }^{56}$ Тематические планы военной подготовки студентов на 1951-1952 уч. г., ДАЛО, ф. Р-120, оп. 12, спр. 108. 
на кожному профілі студенти вивчали й притаманні їм дисципліни, з яких здавали іспити ${ }^{57}$. Так, з профілю ПММ вивчали: організацію та роботу військ у тилу, двигуни внутрішнього згоряння, роботу складів пального, застосування ПММ ${ }^{58}$. Майбутні офіцери запасу військ зв'язку повинні були опанувати роботу військових радіостанцій, телефонну та телеграфну справу, вміти працювати на апаратах Морзе, вивчали джерела електроживлення та наснажногенераторні станції ${ }^{59}$. Із профілю автотракторної служби студенти працювали над матчастиною автомобілів і тракторів, ремонтом і експлуатацією автомобілів, складали іспити з водіння ${ }^{60}$. Із профілю артилерійно-топографічної служби вивчали артилерію, тактику артилерії, а іспит зі стрілецького вишколу проходили на зборах у військах ${ }^{61}$.

Станом на 1955-1956 н. p. військова кафедра проводила навчання ще за одним профілем - “офіцер запасу радіотехнічних засобів виявлення та наведення”, де окрім загальних предметів: муштровий вишкіл, вогневий вишкіл, загальновійськова тактика та ін. вивчали основи радіолокації, матчастину та ремонт радіолокаційних станцій ${ }^{62}$.

Наголосимо, що теоретичне навчання було своєрідним базисом, а свої знання студенти повинні були закріпити на практиці. Саме тому, ключове місце у вишколі офіцерів запасу відводилось для навчальних зборів у військах, де велика увага приділялась практичним навичкам в командуванні чотою (взводом).

У перші повоєнні роки у всіх вишах Львова навчання студентів у таборах було зовсім відсутне ${ }^{63}$. У 1944-1945 н. р. військова кафедра ЛПІ зробила спробу скерувати студентів 2 курсу на збори у військах. Так, у другому семестрі навчального року на військовий вишкіл відвели по 14 годин на тиждень. Кафедра отримала нові автомашини та обладнання зі зв'язку, облаштувала спеціялізовані авдиторії ${ }^{64}$. Проте, попри ці зусилля, збори у військах скасували. Внаслідок, на кафедрі так і не були проведені екзамени у студентів другого курсу із військових дисциплін, які, за програмою, планували провести після табірних зборів.

\footnotetext{
57 Протоколы заседаний кафедры за 1951-1952 уч. г., ДАЛО, ф. Р-120, оп. 12, спр. 109, арк. 30 зв.

58 Тематические планы военной подготовки студентов на 1951-1952 уч. г., ДАЛО, ф. Р-120, оп. 12 , спр. 108

${ }^{59}$ Там само.

${ }^{60}$ Там само.

${ }^{61}$ Там само.

62 Тематические планы военной подготовки студентов на 1955-1956 уч. г., ДАЛО, ф. Р-120, оп. 12 , спр. 108.

63 Звіти про роботу відділу соціального забезпечення. Акти перевірки військової та фізкультурної роботи на підприємствах, в школах, технікумах, і вищих навчальних закладах міста. Довідки працевлаштування інвалідів Вітчизняної війни, забезпечення сімей загиблих воїнів Радянської армії, ДАЛО, ф, П-4, оп. 1, спр. 187, арк. 101.

${ }^{64}$ Отчет о работе института за 1944-1945 уч. г., ДАЛО, ф. Р-120, оп. 5, спр. 2, арк. 63.
} 
ISSN 2078-6077. Наукові зошити історичного факультету Львівського університету. 2018-2019. Випуск 19-20. Proceedings of History Faculty of Lviv University. 2018-2019. Issue 19-20.

У квітні 1946 р. інженер-майор Коваленко П. П. на засіданні кафедри, проінформував, що військові збори в 1946 р. для військової кафедри ЛПІ скасовані ${ }^{65}$. У протоколах засідань кафедри за 1946-1947 н. р. знаходимо відомості про підготову до табірних зборів, що мали відбутися влітку 1947 p. Відповідно до плану 304 студенти, 214 з яких автомобілісти, повинні відбути практику у військах. Передбачено час перебування -20 робочих днів. Табірні збори мали розпочатися в кінці червня. Сотнями (ротами) призначили керувати офіцерів кафедри: підполковника Ільїна, підполковника Чернявського, майора Ляшенка, капітанів М. Волкова, Л. Ковальова, І. Александрова I. та одного офіцера із сільськогосподарського інституту ${ }^{66}$. Та вже в наступному році у доповідній записці начальника кафедри генерал-майора Голубєва А. П. за 13.04.1948 р. начальникові відділу військової підготовки Міністерства Вищої освіти вказано, що табірні збори в 1947-1948 н. р. були скасовані ${ }^{67}$. Отже, вірогідно стверджувати, що в 1947 р. студенти таки пройшли навчання у військах не можемо.

Станом на 1949-1950 н. р. навчальні збори у військах вже проводились ${ }^{* * * * 68}$. Такий практичний вишкіл отримували студенти другого і четвертого курсів ${ }^{69}$. До поїздки їх розподіляли по чотах (взводах) та вибирали командирів, формували комсомольське бюро табірного збору, організовували партійні групи, спорткомітет і призначали агітаторів. Один із офіцерів кафедри перед табірними зборами повинен був поїхати на місце проведення таборів для організації прийому, матеріяльної бази, налагодити забезпечення медичною службою та ин ${ }^{70}$.

Студентів переважно скеровували у військові частини ПрикВО: Тернополя, Яворова, Магерова, проте траплялися випадки, коли табірні збори організовували і за межам військового округу, наприклад, в Одесі 1956 p ${ }^{71}$.

На навчаннях у таборах студенти другого курсу повинні були скласти розрядні норми зі стрільби (3-й розряд), а студенти старших курсів отримували можливість практичної стрільби бойовими набоями ${ }^{72}$. Проте підкреслимо, що

${ }^{65}$ Протоколы заседаний кафедры за 19.04.1946 г. - 23.05.1946 г., ДАЛО, ф. Р-120, оп. 12, спр. 12 , арк. 1.

${ }^{66}$ Протоколи засідань кафедри за 1946-1947 н. р., ДАЛО, ф. Р-120, оп. 12, спр. 20, арк. 22.

${ }^{67}$ Приказы и директивные указания МВО СССР, Управления по делам Высшей школы при Совете Министров УССР и Управления Всеобщего военного обучения Министерства вооруженных сил СССР, ДАЛО, ф. Р-120, оп. 12, спр. 46, арк. 15.

***** Про те, чи проводились табірні збори в 1948-1949 н. р., автор уточнить.

${ }^{68}$ Протоколы заседаний кафедры за 1950-1951 уч. г., ДАЛО, ф. Р-120, оп. 12, спр. 84, арк. $30,36$.

${ }^{69}$ Протоколы заседаний кафедры за 1951-1952 учебный год, ДАЛО, ф. Р-120, оп. 12, спр. 109, арк. 33 зв.

${ }^{70}$ Протоколы заседаний партийного бюро спецкафедры и кафедры физвоспитания ЛПИ (11 марта 1956-14 декабря 1956 г.), ДАЛО, ф. П-380, оп. 1, спр. 183, арк. 19.

${ }^{71}$ Там само, арк. 20.

72 Протоколы заседаний кафедры за 1951-1952 уч. г., ДАЛО, ф. Р-120, оп. 12, спр. 109, арк. 5. 
головна мета таких зборів - виробити практичні навички в командуванні чотою (взводом).

Від початку 1956 р. кардинальних змін у навчанні офіцерів запасу не сталось. Однак, уже в перші місяці після ХХ з'їзду КПРС розпочали повне оновлення навчально-методичної літератури, матеріяльної частини кафедри військової підготовки ЛПІ. Вже у квітні 1956 р. командування штабу ПрикВО, виконуючи наказ Міністерства оборони СРСР № 42 від 02.04.1956 р. “У справах покращення користування статутною і навчальною літературою та підвищення якості бойової підготови артилерійських частин (підрозділів)”, надсилало методичні рекомендації щодо оновлення навчальної бази кафедри. Із певної частини військової літератури знімали гриф “секретно" "73, їх можна було виносити за межі військової кафедри, спростили механізм їхнього обліку; переглянуто фонди діяфільмів, що зберігались на кафедрі як навчально-наочний матеріял, частину 3 них розсекретили, іншу - вилучали, як “застарілі” і як такі, що “не мають цінности для навчання військ”, ще іншу - залишали на кафедрі для проведення занять, однак, при показі деяких із них потрібно було “використовувати методичні рекомендаиії і звертати увагу студентів на окремі засади, щзо суперечили реальним настановам"74.

Отже, на підставі аналізу документації військової кафедри Львівського політехнічного інститугу, преси та партійних документів можна зробити такі висновки:

1. Матеріяльна забезпека військової кафедри вже з перших років існування була достатньою. Кафедра мала у своєму користуванні авдиторний фонд, який поступово збільшувався, гаражі, пізніше автопарк, стрілецький тир. Військова кафедра отримувала все матеріяльне обладнання, зброю, топографічні карти, однак, відчувалась недостача підручників та методичних посібників. Як бачимо, адміністрація інституту не одразу взялась вирішувати питання оснастити військову кафедру. Існувала проблема постійного приміщення кафедри, яке керівництво інституту намагалось вирішити лише на початку 1950-х рр.

2. Офіцерський склад кафедри варіювався згідно зі штатним розписом інституту, а також упродовж означеного нами часу. Так, від 1944 до 1946 pp. штат військової кафедри був не затверджений, а тому спостерігаються часті зміни кількости працівників кафедри. Від 1946 р. помітно збільшується кількісний та якісний склад офіцерів, що зумовлено розвитком самої кафедри та збільшенню кількости профілів військового вишколу студентів. Упродовж дослідженого нами періоду кафедру очолювали два начальники: інженер-підполковник Коваленко П. П. (1944-1946) та генерал-майор Голубєв А. П. (1946-1957).

3. Офіцери кафедри військової підготовки проводили активну військовополітичну роботу в інституті. При кожному факультеті призначали факультетського курсового офіцера, завданням якого було проводити військово-

\footnotetext{
73 Директивные указания и письма Управления вневойсковой подготовки Министерства обороны СССР и управлений ПрикВО, ДАЛО, ф. Р-120, оп. 12, спр. 211, арк. 2.

${ }^{74}$ Там само, арк. 4.
} 
ISSN 2078-6077. Наукові зошити історичного факультету Львівського університету. 2018-2019. Випуск 19-20. Proceedings of History Faculty of Lviv University. 2018-2019. Issue 19-20.

політичні та патріотичні заходи. Окрім того, він вивчав біографії студентів, що навчались на кафедрі, заводив на кожного студента окрему особову справу, писав на них характеристики.

4. Важливим елементом військово-патріотичної роботи кафедри було залучення офіцерів військової кафедри та студентів до занять у секціях ДТСААФ. Наприкінці 1940-х - початку 1950-х рр. в інституті діяли авто-, мото-, радіо- та стрілецька секції, секція зв'язку.

5. Від 1944 р. військова кафедра готувала офіцерів запасу за двома військовими спеціяльностями: “офіцер запасу автомобільних військ” та “офіцер запасу військ зв’язку”. 3 розвитком кафедри, збільшувалась кількість профілів військового навчання. У 1948-1949 н. р. на військовій кафедрі запровадили ще два профілі вишколу " “офіцер запасу служби постачання паливно-мастильних матеріялів” та “офіцер запасу артилерійно-топографічної служби”. На 19551956 н. р. військова кафедра проводила навчання за ще одним профілем вишколу “офіцер запасу радіотехнічних засобів виявлення та наведення". Незалежно від профілів вишколу, студенти проходили муштровий вишкіл, військову топографію, вогневий вишкіл, загальновійськову тактику, військово-інженерний вишкіл, протихімічний вишкіл та вивчали статути. Також студенти вивчали профільні дисципліни, з яких здавали іспити.

6. Основні практичні навички стрільби, роботи із військовою технікою та досвід роботи на бойових машинах студенти отримували на табірних зборах. Однак, у перші повоєнні роки (1944-1946) у всіх вишах Львова навчання студентів в таборах не відбувалось. Бачимо, що в 1947 р. військова кафедра планувала скерувати студентів на навчання у військах на 20 робочих днів, однак, стверджувати, що воно відбулося, ми не можемо, оскільки вже в наступному 1947-1948 н. р. табірні збори були скасовані. В 1949-1950 н. р. табірні збори вже проводили. Практичний вишкіл отримували студенти другого і четвертого курсів. Їх переважно скеровували у військові частини ПрикВО, проте траплялися випадки, коли табірні збори організовували і за межам військового округу, наприклад в Одесі.

Загалом, упродовж 1944-1956 pр. кафедра військової підготовки ЛПІ хоч і виконувала навчальну програму військового вишколу офіцерів запасу, однак говорити про достатні навики студентів в опануванні військової справи ми не можемо. Існували проблеми матеріяльної забезпеки, приміщень, що завадило проводити військовий вишкіл студентів на високому рівні. А найважливішою проблемою була та, що студенти в перші повоєнні роки не мали можливости навчатись у військах, що негативно вплинуло на їхній практичний вишкіл та бойову готовість. Врешті - і на евентуальну боєздатність Радянської Армії. 
ISSN 2078-6077. Наукові зошити історичного факультету Львівського університету. 2018-2019. Випуск 19-20. Proceedings of History Faculty of Lviv University. 2018-2019. Issue 19-20.

\title{
THE MILITARY DEPARTMENT OF LVIV POLYTECHNIC INSTITUTE IN THE POSTWAR DECADE (1944-1956)
}

\author{
Larysa SHELESTAK \\ Ivan Franko National University of Lviv \\ Department of Local History \\ Universytetska str., 1, Lviv, 79000, Ukraine \\ e-mail: larashelestak@ukr.net
}

\begin{abstract}
Ukraine has been involved into war with Russia lately and Ukrainian Government is trying to improve the system of military training. That's why, The Ukraine's Cabinet of Ministers issued a resolution "On the Optimization of the Network of Military Departments of Universities". According to the document military departments have been created in several universities located all around Ukraine. This resolution shows that the Government tries to use past methods to increase the military potential of the country - training programs of reserve officers at the military departments of civilian higher educational institutions. That is why we decided to show specifics of military training at Lviv Polytechnic Institute in 1944-1956: from the beginning of establishment Soviet power in 1944 up to The 20th Congress of the Communist Party of the Soviet Union in 1956 and changes in political and ideological life in the USSR after it.

The material support of the military department from the very first years was sufficient. The department had classes, garages, later - different combat vehicles, and a shooting ranges in use. The main problem was the building of permanent location of the department, which was solved only in the early 1950 's. During the researched period the department was headed by two chiefs: Lieutenant Colonel Kovalenko P. (1944-1946) and Major General Golubev A. (1946-1957).

The tasks of military department of Lviv Polytechnic Institute were not only just training the officers. It also served as a key link in the ideological and political work. In order to identify "Ukrainian bourgeois nationalists", the teachers of the department filled up so called personal file for every student, with information about origin, parents and family.

At the beginning, in 1944, the Institute was preparing reserve officers for two military specialties: "Reserve officer of automobile troops" and "Reserve officer of Signal Corps". In 1948-1949 academic year the military training started for two more specialties: "Reserve officer of fuel, oil and lubricants supply service" and "Reserve officer of artillery and topographic service". In 1955-1956 the department had been trained students for one more military specialty - "Reserve officer of radio equipment for detection and guidance". Regardless of the profiles, students were trained in artillery training, military topography, fire training, tactics, military engineering training, anti-chemical training and studying statutes. Also, students studied the specialized disciplines according to their military specialty.

Students received basic practical skills in firing, experience in use combat vehicles and experience in command troops at camp meetings in the troops. However, in the first postwar years, military training in the troops was completely absent for students of all higher educational establishments of Lviv. On a regular basis, camp meetings in the troops for Institute's students started from 1949-1950 academic year. Only students of the second and fourth year were sent to the practical training in military units.

Consequently, the author of the article shows features of military training at Lviv Polytechnic Institute in 1944-1956. In general, there were problems of material support, in particular the building of permanent location of the military department. The most important problem was that students in the first post-war years did not have the opportunity to study in the troops, which adversely affected their practical training and combat readiness.

Keywords: Lviv Polytechnic Institute, military department, military education, reserve officers, camp meetings in the troops.
\end{abstract}


ISSN 2078-6077. Наукові зошити історичного факультету Львівського університету. 2018-2019. Випуск 19-20. Proceedings of History Faculty of Lviv University. 2018-2019. Issue 19-20.

\section{REFERENCES}

Braz, Oleksandr. "Peremoha instytutskykh mototsyklistiv na miskomu krosi," Radianskyi student, No. 22. (9 chervnia 1949): 4. (in Ukrainian)

Butsko, Mykola. Derzhavnyi universytet "Lvivska politekhnika”: 1894-1994. Lviv: Vydavnytstvo Derzhavnoho universytetu "Lvivska politekhnika", 1994, 145. (in Ukrainian)

"Holubev Arkadii Pavlovich", Kavalery yubileinoi medali “XX let RKKA”, 25 noiabria 2012, otrymano dostup 9 serpnia 2018, http://zov1941.ucoz.ru/index/golubev_arkadij_pavlovich/ 0-244 (in Russian)

"Holubev Arkadii Pavlovich," Stranytsy rossyiiskoi istorii: Liudy, sobytiia, vospominaniia, dokumenty..., otrymano dostup 9 serpnia 2018, http://russian-dossier.ru/taxonomy/term/ 5977 (in Russian)

Direktivnyie ukazaniia i pisma Upravleniia vnevoiskovoi podhotovki Ministerstva oborony SSSR i upravlenyi PrykVO, Derzhavnyi Arkhiv Lvivskoi Oblasti, f. R-120, op. 12, spr. 211, ark. 2. (in Russian)

Dovidnyk pereimenuvan vulyts i ploshch Lvova XIII-XX st., red. B. V. Melnyk, Lviv: Svit, 2001, 128. (in Ukrainian)

Zvity pro robotu viddilu socialnoho zabezpechennia. Akty perevirky viiskovoi ta fizkulturnoi roboty na pidpryiemstvakh, v shkolakh, tekhnikumakh, i vyshchykh navchalnykh zakladakh mista. Dovidky pratsevlashtuvannia invalidiv Vitchyznianoi viiny, zabezpechennia simei zahyblykh voiniv Radianskoi armii, Derzhavnyi Arkhiv Lvivskoi Oblasti, f, P-4, op. 1, spr. 187, ark. 101. (in Ukrainian)

Informaciia i zvity pro robotu partorhanizatsii, Derzhavnyi Arkhiv Lvivskoi Oblasti, f. P-380, op. 1, spr. 22, ark. 70. (in Ukrainian)

Istorychna dovidka Lvivskoho Politekhnichnoho instytutu, Derzhavnyi Arkhiv Lvivskoi Oblasti, f. R-120, (Posylaiuchys na f. R-120, op. 32, spr. 2, ark. 11-13, 29-30.) (in Ukrainian)

Istorychna dovidka Lvivskoho Politekhnichnoho instytutu, Derzhavnyi Arkhiv Lvivskoi Oblasti, f. R-120, (Posylaiuchys na f. R-120, op. 6, spr. 92-a, ark. 6.) (in Ukrainian)

Kabinet Ministriv Ukrainy. Postanova vid 10 bereznia 2017 r. No. 133 "Pro utvorennia viiskovykh navchalnykh pidrozdiliv vyshchykh navchalnykh zakladiv ta vnesennia zmin u dodatok do Poriadku provedennia viiskovoi pidhotovky hromadian Ukrainy za prohramoiu pidhotovky ofitseriv zapasu", Verkhovna Rada Ukrainy, otrymano dostup 01.07.2018, http://zakon.rada.gov.ua/laws/show/133-2017-\%D0\%BF (in Ukrainian)

Otchet o rabote voennoi kafedry za 1945-1946 uch. g., Derzhavnyi Arkhiv Lvivskoi Oblasti, f. R-120, op. 12, spr. 11, ark. 15-16. (in Russian)

Otchet o rabote instituta za 1944-1945 uch. g., Derzhavnyi Arkhiv Lvivskoi Oblasti, f. R-120, op. 5, spr. 2, ark. 131. (in Russian)

Otchet o rabote instituta za 1945-1946 uch. g., Derzhavnyi Arkhiv Lvivskoi Oblasti, f, R-120, op. 5, spr. 4, ark. 95. (in Russian)

Pidsumkova dopovid pro rezultaty marksystsko-leninskoi pidhotovky ofitseriv viiskovykh kafedr i viiskovii pidhotovtsi studentiv vyshiv Prykarpatskoho Viiskovoho Okruhu za 1948-1949 n. r., Derzhavnyi Arkhiv Lvivskoi Oblasti, f. P-4 (Lvivskyi miskyi komitet KPU), op. 1, spr. 315, ark. 94. (in Ukrainian)

Pogranets. Vsiesoiuznyi forum pogranichnikov, 29 zhovtnia 2013, otrymano dostup 9 serpnia 2018, http://www.pogranec.ru/showthread.php?t=25117\&page=11 (in Russian)

Postanovleniie SNK SSSR, direktivnyie pisma SNK USSR i Vsesoiuznogo kabineta po delam vysshei shkoly pry SNK SSSR (1945-1946), Derzhavnyi Arkhiv Lvivskoi Oblasti, f. R-120, op. 12, spr. 10, ark. 5. (in Russian) 
ISSN 2078-6077. Наукові зошити історичного факультету Львівського університету. 2018-2019. Випуск 19-20. Proceedings of History Faculty of Lviv University. 2018-2019. Issue 19-20.

Prikazy i direktivnyie ukazaniia MVO SSSR, Upravleniia po delam Vysshei shkoly pry Sovietie Ministrov USSR i Upravlieniia Vseobshchego voiennogo obucheniia Ministerstva Vooruzhennykh Sil SSSR, Derzhavnyi Arkhiv Lvivskoi Oblasti, f. R-120, op. 12, spr. 46, ark. 16. (in Russian)

Protokoly zasidan kafedry za 1946-1947 n. r., Derzhavnyi Arkhiv Lvivskoi Oblasti, f. R-120, op. 12, spr. 20, ark. 32. (in Ukrainian)

Protokoly zasidan partiinoho biuro 1949 r., Derzhavnyi Arkhiv Lvivskoi Oblasti, f. P-380, op. 1, spr. 50, ark. 267. (in Ukrainian)

Protokoly zasidan partiinoho biuro za 1950 r., Derzhavnyi Arkhiv Lvivskoi Oblasti, f. P-380, op. 1, spr. 68, ark. 293. (in Ukrainian)

Protokoly zasiedanii kafedry(1953-1954 uch. g.), Derzhavnyi Arkhiv Lvivskoi Oblasti, f. R-120, op. 12, spr. 142. ark. 75. (in Russian)

Protokoly zasiedanii kafedry za 19 aprelia 1946 g.-23 maia 1946 g., Derzhavnyi Arkhiv Lvivskoi Oblasti, f. R-120, op. 12, spr. 12, ark. 32. (in Russian)

Protokoly zasiedanii kafedry za 1950-1951 uch. g., Derzhavnyi Arkhiv Lvivskoi Oblasti, f. R-120, op. 12, spr. 84, ark. 36. (in Russian)

Protokoly zasiedanii kafedry za 1951-1952 uch. g., Derzhavnyi Arkhiv Lvivskoi Oblasti, f. R-120, op. 12, spr. 109, ark. 35. (in Russian)

Protokoly zasiedanii kafedry za 1952-1953 uch. g., Derzhavnyi Arkhiv Lvivskoi Oblasti, f. R-120, op. 12, spr. 123, ark. 34. (in Russian)

Protokoly zasiedaniia partiinogo biuro za 1945 g., Derzhavnyi Arkhiv Lvivskoi Oblasti, f. P-380, op. 1, spr. 3, ark 24. (in Russian)

Protokoly zasiedanii partiinogo biuro spetskafedry i kafedry fizvospitaniia LPI (11 marta 195614 dekabria 1956 g.), Derzhavnyi Arkhiv Lvivskoi Oblasti, f. P-380, op. 1, spr. 183, ark. 27. (in Russian)

Tematichieskiie plany voiennoi podgotovki studientov na 1951-1952 uch. g., Derzhavnyi Arkhiv Lvivskoi Oblasti, f. R-120, op. 12, spr. 108, ark. 242. (in Russian) 
